\title{
The Effects of Microwave Radiation on Microbial Cultures
}

\author{
Slobodan M. Janković, Milorad Z. Milošev, Milan LJ. Novaković \\ Faculty of Medical Sciences, University of Kragujevac, Kragujevac, Serbia
}

\section{SUMMARY}

Microwaves are non-ionizing electromagnetic waves with frequencies between 0.3 and 300 $\mathrm{GHz}$. Both humans and microorganisms living on the human body are exposed to significant doses of microwave radiation in everyday life. Whether and how microwave radiation could influence the viability and growth of microorganisms is the subject of this educational paper.

Studies on the effects of microwaves on the growth of microbial cultures were searched for in biomedical journals indexed in MEDLINE from 1966 to 2012. The published studies showed that microwaves produce significant effects on the growth of microbial cultures, which vary from the killing of microorganisms to enhancement of their growth. The nature and extent of the effect depend on the frequency of microwaves and the total energy absorbed by the microorganisms. Low energy, low frequency microwaves enhance the growth of microorganisms, whereas high energy, high frequency microwaves destroy the microorganisms. However, neither the effects of a wide spectrum of frequencies nor the effects of a wide range of absorbed energies have been investigated.

Considering the potentially deleterious influence of microwaves on the symbiotic balance between microorganisms and the human host, further research on the effects of the complete frequency and energy spectra of microwave radiation on the growth of microorganisms is necessary.

Keywords: microwaves; microbial cultures; frequency; absorbed energy; growth

\section{INTRODUCTION}

Interactions between various types of electromagnetic radiation and living organisms have attracted the attention of scientists since the introduction of technical devices that operate using electromagnetic waves. In the last decade, the human population has been increasingly exposed to radiation from microwave-operating devices, such as radars, diathermy devices, and cellular or cordless phones; in the first quarter of 2012 the number of mobile phone users in China increased to 1 billion [1]. Together with humans, thousands of bacterial species and yeasts living on or in the human body are exposed to significant doses of microwave radi- ation. Whether and how microwave radiation could influence the viability (ability of microorganisms to survive in hostile environment), pathogenicity (ability of microorganisms to cause a disease) and growth of microorganisms is the subject of this review.

\section{MICROWAVES}

Microwaves are non-ionizing electromagnetic waves with frequencies between 0.3 and 300 $\mathrm{GHz}$ (i.e., with wavelengths from 1 meter to 1 millimetre, respectively) [2]. The most important sources of microwave radiation that humans may encounter are various industrial microwave 
generators used for communications, that speed up chemical reactions or are used for heating (896 or $915 \mathrm{MHz}$ ); cellular phones $(824-850$, 900,1800 or $1900 \mathrm{MHz}$ ); cordless phones (from 46 to $5800 \mathrm{MHz}$ ); microwave ovens (915 and $2450 \mathrm{MHz}$ ); certain diathermy applicators (915 and $2450 \mathrm{MHz}$ ); UHF radios (from 470 to 890 $\mathrm{MHz}$ ); dish antennas (from 0.8 to $15 \mathrm{GHz}$ ); and traffic radar (10.5 and $24 \mathrm{GHz}$ ). The energy of microwaves is relatively low: one quantum has approximately $10^{-5}$ electron volts $(\mathrm{eV})$, which is considerably lower than the quantum energy needed for the ejection of an electron from a molecule or the breaking of an intra-molecular bond (> $10 \mathrm{eV}$ ) [3]; therefore, microwave radiation is considered non-ionizing radiation.

\section{MECHANISM OF MICROWAVES ACTION ON LIVING ORGANISMS}

When irradiating living organisms, microwaves produce two types of effects: thermal and non-thermal. Thermal effects are the consequence of absorption of microwave energy by cell molecules, causing them vibrate much faster and producing general heating of the cell [3]. The extent of microwave absorption within a cell depends on its dielectric constant and electrical conductivity [3]. The concept of non-thermal effects of microwaves came from experiments in which bacterial cultures were to a large extent destroyed by microwave-induced heating than by other heating methods producing the same working temperature and from studies showing an increase in the growth of bacteria induced by microwaves [4]. The mechanism of the non-thermal action of microwaves is still not completely understood. However, it seems that changes in the secondary and/or tertiary structure of functional proteins ensue as a consequence of rotation and lining-up of the molecules with a rapidly alternating electric field (more than a billion times per second) [4].

\section{SYMBIOSIS BETWEEN MICROORGANISMS AND HUMAN HOSTS}

Billions of bacterial cells and yeasts live on the human skin and mucosal surfaces, engaging in a symbiotic relationship with the host. Recently, it was estimated that 500 to 1,000 species of bacteria live in the human gut. Symbiotic bacteria are useful to humans in a variety of ways: they promote digestion of food and absorption of nutrients, they synthesise vitamins (vitamin $\mathrm{K}$ and biotin), they prevent the colonization of pathogenic bacteria, and they improve functioning of the immune system [5]. Symbiotic bacteria on human skin even stimulate the production of antimicrobial peptides by the cells of the skin epithelium, aiding the skin's defense against pathogenic bacteria [6]. However, the disruption of this symbiosis by external factors, which either massively destroy commensals (e.g., by antiseptics or antibiotics) or excessively increase their growth (e.g., blind intestinal loop syndrome or excretion of dextrose in urine), may have adverse consequences on human health and decrease defence against pathogenic microbes [7]. In this way, many serious bacterial infections may ensue, like gastroenteritis, pneumonia, urinary tract infections, skin infections, etc. Considering the overwhelming presence of microwave radiation in the human environment, interactions between microwaves and microorganisms have great potential to significantly influence human health.

\section{EFFECTS OF MICROWAVE RADIATION ON MICROORGANISMS}

\section{Overall effects on growth}

How microwaves will affect the growth of microorganisms depends primarily on the frequency of the radiation and the total energy absorbed by the microorganisms (absorbed dose). When microwaves are applied at certain frequencies, with high energy and for a sufficiently long period of time, their thermal effect is most likely dominant and kills bacterial cells or yeasts. Numerous experiments with microwave irradiation of various cultures of bacteria and yeasts in a wet environment such as a water suspension did not show additional killing of the microbes by microwaves compared to that caused by conventional heating to the same temperature $[8,9,10]$. However, in a dry environment, the killing effect of microwave radiation was significantly decreased and happened only after a prolonged period of irradiation, most likely due to a lower transformation of microwave energy to heat. Some of the studies even showed that the extent of killing of microorganisms (bacteria and bacteriophages [viruses that attack bacteria]) was correlated 
with the moisture content of the experimental specimens.

In contrast, when microorganisms were irradiated with microwaves at temperatures lower than the thermal destruction level; various effects were observed, from killing to enhanced growth. A specific killing effect of microwaves on Escherichia coli, different from the effect of hyperthermia, was observed in several studies [11].

\section{Thermal effects on growth}

Because it was observed that the heating of microorganisms to a certain temperature by microwaves could kill them, many studies were performed attempting to establish the minimal dose of microwave energy that could be used for disinfection or sterilization purposes. In a study on toothbrushes contaminated with Streptococcus mutans, a type of bacteria that can cause dental caries, radiation from a microwave oven at "high power" for five minutes completely decontaminated the toothbrushes; it was more effective than the antiseptic cetylpyridinium chloride or UV-radiation [12]. Another study showed that microwaves could be effectively used for reducing the number of bacteria on previously worn dentures [13]. Microwaves with frequencies of $18 \mathrm{GHz}$, used on bacteria that contaminated bovine pericardium prepared for the construction of artificial heart valves, showed a strong inactivating effect. Cultures of Staphylococcus aureus and Escherichia coli were completely inactivated after three consecutive exposures to radiation with such characteristics [14]. When cultures of Escherichia coli and spores of Bacillus cereus were exposed to the maximum microwave power in a home microwave oven, they were completely destroyed after two and four minutes, respectively [15].

The thermal killing effect of microwaves is non-selective, and various species of microorganisms will also be destroyed if a sufficient dose is used (Table 1). When cultures of Pseudomonas aeruginosa, Staphylococcus aureus, Candida albicans, and Bacillus subtilis contaminating dental resin were irradiated with microwaves in a wet environment at $650 \mathrm{~W}$ for $1,2,3,4$ or 5 minutes, the killing effect was observed after an exposure of two minutes or longer. Candida albicans was more susceptible to microwave radiation than bacterial cultures
[16]. Similar effects were obtained for microwaves irradiating the same species of bacteria inoculated on dentures in a wet environment at $650 \mathrm{~W}$ for 6 minutes. S. aureus and C. albicans inoculums were completely destroyed, while the number of $\mathrm{P}$. aeruginosa and $\mathrm{B}$. subtilis cells was greatly reduced [17]. Being non-selective, the killing effect of microwaves is synergistic with the effects of other non-selective killing agents, such as disinfectants. In a study of the interaction between microwaves and the disinfectant hydrogen peroxide $(0.08 \%)$, the synergistic killing effect was achieved on Escherichia coli and Pseudomonas aeruginosa cultures after exposure for 10 minutes and a maximum obtained temperature of $60^{\circ} \mathrm{C}$ [11]. Some environmental conditions may diminish the deleterious thermal effect of microwaves on microbes, including an increase in the concentration of sodium chloride within the extracellular medium. When cultures of Staphylococcus aureus, Salmonella enteritidis, Escherichia coli and Bacillus cereus inoculated in a mashed potato preparation were exposed to microwave $(2450 \mathrm{MHz})$ heating for $1 \mathrm{~min}$ at 800 $\mathrm{W}$, the percentage of killed cells was inversely proportional to the concentration of sodium chloride in the medium [18].

\section{Non-thermal effects on growth}

2An interesting finding was made in the study of Grundler et al. [22]: at frequencies of 41, 64041 , and $835 \mathrm{MHz}$, microwaves showed a resonant-like effect on the growth of some yeasts, including Saccharomyces cerevisiae, which was not dependent on the amount of absorbed energy from the microwaves. The growth was interchangeably enhanced or decreased at steps of $10 \mathrm{MHz}$ within the frequency range studied. The mechanism of this effect could not be explained by the authors.

\section{Possible mechanisms of non-thermal effects of microwaves on microbial cultures}

Understanding the mechanism of non-thermal action of microwaves on microorganisms is very important for the possible future use of microwave technology or for avoidance of its deleterious effects on humans, who live in symbiosis with microbes. Not much is known 
Table 1. Effects of microwaves on microbial cultures depending on the frequency, power (or delivered energy) and microbial species

\begin{tabular}{|c|c|c|c|c|c|}
\hline $\begin{array}{l}\text { Delivered } \\
\text { energy }\end{array}$ & \multicolumn{5}{|c|}{ Frequency of microwaves } \\
\hline Not reported & & & & $\begin{array}{l}\text { Saccharomyces } \\
\text { cerevisiae, } \\
\text { INCREASED/ } \\
\text { DECREASED } \\
\text { GROWTH }\end{array}$ & \\
\hline $\begin{array}{l}550 \mathrm{~W}, 5-30 \\
\text { seconds }\end{array}$ & & $\begin{array}{l}\text { P. aeruginosa, P. acidovorans, S. } \\
\text { aureus and S. epidermidis, } \\
\text { ENHANCED GROWTH }\end{array}$ & $\begin{array}{l}\text { S. aureus, E. coli, } \\
\text { INACTIVATION }\end{array}$ & & \\
\hline 800 W, 1 minute & & $\begin{array}{l}\text { S. aureus, Salmonella enteritidis, E. } \\
\text { coli and B. cereus, KILLED }\end{array}$ & & & \\
\hline $\begin{array}{l}10 \text { and } 60 \\
\mathrm{~mW} / \mathrm{cm}^{2} \\
5-60 \text { minutes }\end{array}$ & & $\begin{array}{l}\text { Aspergillus versicolor and } \\
\text { Penicillium brevicompactum) and } \\
\text { actinomycetal (Thermoactinomyces } \\
\text { vulgaris and Streptomyces albus) } \\
\text { spores, VIABILITY OF FUNGI } \\
\text { DECREASED, VIABILITY OF } \\
\text { ACTINOMYCETES INCREASED }\end{array}$ & & & \\
\hline $1500 \mathrm{~kW} / \mathrm{m}^{2}$ & & & $\begin{array}{l}\text { E. coli, } \\
\text { OPENINGS OF } \\
\text { PORES in the } \\
\text { cell membrane }\end{array}$ & & \\
\hline
\end{tabular}

about the mechanisms because previous studies have been limited in number and scope [23]. In a study in which Escherichia coli cultures were exposed to microwaves $(18 \mathrm{GHz}$, absorbed power $1500 \mathrm{~kW} / \mathrm{m}^{2}$, electric field $300 \mathrm{~V} / \mathrm{m}$ ) at temperatures below $40^{\circ} \mathrm{C}$ (to avoid the thermal effects of microwaves), transient morphological changes (dehydrated appearance) and openings of pores in the cell membrane (approximately $20 \mathrm{~nm}$ in diameter, enabling passage of dextran molecules) were observed [24]. It seems that this effect is electro kinetic in nature (caused by increased movements of anions and cations), causing localized structural disarrangements of the cell membrane, which results in the emergence of pores. Large membrane pores cause leakage of vital intracellular molecules out of the bacterial cells, which may lead to their death. The effect was reversible because more than $87 \%$ of exposed cells remained viable. Similar effects of microwaves on cell membranes were observed in another study [25] in which Bacillus licheniformis spores were irradiated with microwaves (2450 $\mathrm{MHz}, 2$ minutes, $2 \mathrm{~kW}$ ), which caused spore cortex hydrolysis (brake of molecular bonds by insertion of water), swelling and finally rupture, as well as rupture of the inner membrane. This effect could be attributed to the non-thermal action of microwaves because the same temperature (as produced by the microwaves) did not cause such changes in the spore coat and inner membrane. When microwave radiation of the same characteristics was applied to Bacillus subtilis vegetative forms [26], cell walls were disrupted, and the aggregation of cytoplasmic 
(intracellular) proteins was detected on transmission electron microscopy. Both the aggregation of cytoplasmic proteins and swelling of the cell wall were observed in Escherichia coli and Bacillus subtilis after microwave irradiation $(2450 \mathrm{MHz}$ and $600 \mathrm{~W}$ at 40, 60 and 80 degrees of Celsius); these effects could not be attributed to thermal damage because the same temperatures from other heat sources did not produce similar changes [27]. The disintegrating effect of microwave irradiation is time-dependent, where the intensity of the cell wall damage is proportional to the total absorbed microwave energy. Increases in irradiation time from 0 to 9 minutes resulted in a gradual increase in the extracellular soluble chemical oxygen demand, from 0.14 to $2.38 \mathrm{~g} / \mathrm{L}$ (i.e., 72 -fold).

Apart from their effects on cell membranes, microwaves cause non-thermal acceleration of enzymatic reactions in microbial cells, such as non-aqueous esterification (formation of ester-type of chemical compounds without participation of water), and this effect is substrate concentration-dependent [28]. Moreover, microwaves can accelerate synthesis of glycopeptides in vitro (out of the living cells), which may occur in microbial cells, changing their functions [29]. It was shown in human cells that microwaves could decrease the expression and activity of certain functional proteins that cause apoptosis. When SH-SY5Y cells, obtained by retinoic acid-induced differentiation of human neuroblastoma cells, were exposed for $2 \mathrm{~h}$ and 4 $\mathrm{h}$ to microwaves at a $1800 \mathrm{MHz}$ frequency, markers of apoptosis (heat-shock proteins 20,27 and 70 , caspase-3) were not increased. Instead, the expression of Hsp 20 was decreased, potentially prolonging survival of the tested cells [30]. Such effect led to prolonged survival and increased growth of neuroblastoma cells, originating from an extremely malignant cancer. Similar stimulatory effects of microwaves on growth of Escherichia coli cultures were noted, but the exact molecular mechanism of the effect was not discovered. The irradiation of suspensions of Escherichia coli by microwaves at a frequency of $99 \mathrm{GHz}$ for 19 hours caused a slight increase in proliferation of the bacteria compared with control suspensions. The mechanism of this effect was not clear because the irradiation did not influence approximately 90 different biochemical reactions within the Escherichia coli cell that were tested in the same study $[31,32]$.

\section{CONCLUSIONS}

Many studies show that microwave radiation can have significant effects on the growth of microbial cultures, which can vary from killing of microorganisms to enhancement of their growth. The nature and extent of the effects depend on the microwave frequency and the total energy absorbed by the microorganisms. It seems that low energy, low frequency microwaves enhance the growth of microorganisms, while high energy, high frequency microwaves destroy the microorganisms. However, neither the effects of a wide spectrum of frequencies nor the effects of a wide range of absorbed energies were investigated. Considering the potentially deleterious influence of microwaves on the symbiotic balance between microorganisms and the human host, there is a high demand for further research on the effects of the complete frequency and energy spectra of microwave radiation on the growth of microorganisms.

\section{ACKNOWLEDGEMENTS}

This review was partially financed by Grant No 175007 from the Serbian Ministry of Education and by a Grant awarded by the Ministry of Science of Montenegro.

\section{Conflict of Interest Statement}

The authors certify that there are no potential conflicts of interest.

\section{REFERENCES}

1. Anonymous, "China mobile phone users exceed 1 billion," China Daily, Xinhua, April the 29th, 2012. Available from: http://www.chinadaily. com.cn/china/2012-03/30/content_14954435. htm accessed on April the 29th, 2012.

2. Balbani AP, Montovani JC. Mobile phones: influence on auditory and vestibular Systems. Braz J Otorhinolaryngol. 2008; 74:125-31.

3. Michaelson SM. Effects of exposure to microwaves: problems and perspectives. Environ Health Perspect. 1974; 8:133-55.

4. Banik S, Bandyopadhyay S, Ganguly S. Bioeffects of microwave - a brief review. Bioresour Technol. 2003; 87:155-9.

5. Curtis MM, Sperandio V. A complex relationship: the interaction among symbiotic microbes, invading pathogens, and their mammalian host. Mucosal Immunol. 2011; 4:133-8. 
6. Gallo RL, Nakatsuji T. Microbial symbiosis with the innate immune defence system of the skin. J Invest Dermatol. 2011; 131:1974-80.

7. Neish AS. Microbes in gastrointestinal health and disease. Gastroenterology. 2009; 136:65-80.

8. Górny RL, Mainelis G, Wlazlo A, Niesler A, Lis DO, Marzec $S$, et al. Viability of fungal and actinomycetal spores after microwave radiation of building materials . Ann Agric Environ Med. 2007; 14:313-24.

9. Vela GR, Wu JF. Mechanism of lethal action of 2,450-MHz radiation on microorganisms. Appl Environ Microbiol. 1979; 37:550-3.

10. Duhain GL, Minnaar A, Buys EM. Effect of chlorine, blanching, freezing, and microwave heating on Cryptosporidium parvum viability inoculated on green peppers. J Food Prot. 2012; 75:936-41.

11. Kuchma TN, Alipov ED, Samoilenko LL, Lystsov VN. Comparative analysis of mechanisms of the modification of microorganism viability under the effect of UHF heating and hyperthermia. Radiobiologiia. 1992; 32:881-6.

12. Bélanger-Ginquére $S$, Bélanger $M$. Disinfection of toothbrushes contaminated with Streptococcus mutans. Am J Dent. 2011; 24:155- 8.

13. Glass RT, Conrad RS, Bullard JW, Goodson LB, Mehta N, Lech SJ, et al. Evaluation of cleansing methods for previously worn prostheses. Compend Contin Educ Dent. 2011; 32:68-73.

14. Patel SS, Owida AA, Morsi YS. Microwave sterilization of bovine pericardium for heart valve applications. J Artif Organs. 2010; 13:24-30.

15. Park DK, Bitton G, Melker R. Microbial inactivation by microwave radiation in the home environment. J Environ Health. 2006; 69:17-24.

16. Mima EG, Pavarina AC, Neppelenbroek KH, Vergani CE, Spolidorio DM, Machado AL. Effect of different exposure times on microwave irradiation on the disinfection of a hard chairside reline resin. J Prosthodont. 2008; 17:312-7.

17. Silva MM, Vergani CE, Giampaolo ET, Neppelenbroek KH, Spolidorio DM, Machado AL. Effectiveness of microwave irradiation on the disinfection of complete dentures. Int J Prosthodont. 2006; 19:288-93.

18. Hayashi M, Shimazaki Y, Kamata S, Kakiichi N. Effects of sodium chloride on destruction of microorganisms by microwave heating in potatoes. Nihon Koshu Eisei Zasshi. 1991; 38:431-7.

19. Atmaca S, Akdaq Z, Dasdag S, Celik S. Effect of microwaves on survival of some bacterial strains . Acta Microbiol Immunol Hung. 1996; 43:371-8.
20. Oliveira EA, Noqueira NG, Innocentini MD, Pisani $\mathrm{R} J$ r. Microwave inactivation of Bacillus atrophaeus spores in healthcare waste. Waste Manag. 2010; 11:2327-35.

21. Zhao J, Monteiro MA. Hydrolysis of bacterial wall carbohydrates in the microwave using trifluoroacetic acid. Carbohydr Res. 2008; 343:2498-503.

22. Grundler W, Keilmann F, Putterlik V, Strube D. Resonant-like dependence of yeast growth rate on microwave frequencies. $\mathrm{Br} J$ Cancer Suppl. 1982; 5:206-8.

23. Zhou BW, Shin SG, Hwang K, Ahn JH, Hwang S. Effect of microwave irradiation on cellular disintegration of Gram positive and negative cells. Appl Microbiol Biotechnol. 2010; 87:76570.

24. Yury S, Alex T, Natasa MD, Rodney C, Russell JC, Elena PI. Specific electromagnetic effects of microwave radiation on Escherichia coli Appl Environ Microbiol. 2011; 77:3017-23.

25. Kim SY, Shin SJ, Song CH, Jo EK, Kim HJ, Park JK. Destruction of Bacillus licheniformis spores by microwave irradiation. J Appl Microbiol. 2009; 106:877-85.

26. Kim SY, Jo EK, Kim HJ, Bai K, Park JK. The effects of high-power microwaves on the ultrastructure of Bacillus subtilis. Lett Appl Microbiol. 2008; 47:35-40.

27. Woo IS, Rhee IK, Park HD. Differential damage in bacterial cells by microwave radiation on the basis of cell wall structure. Appl Environ Microbiol. 2000; 66:2243-7.

28. Wan HD, Sun SY, Hu XY, Xia YM. Non-thermal effect of microwave irradiation in nonaqueous enzymatic esterification. Appl Biochem Biotechnol. 2012; 166:1454-62.

29. Garcia-Martin F, Hinou H, Matsushita T, Hayakawa $S$, Nishimura S. An efficient protocol for the solid-phase synthesis of glycopeptides under microwave irradiation. Org Biomol Chem. 2012; 10:1612-7.

30. Cohen I, Cahan R, Shani G, Cohen E, Abramovich . Effect of $99 \mathrm{GHz}$ continuous millimeter wave electro-magnetic radiation on $\mathrm{E}$. coli viability and metabolic activity. Int J Radiat Biol. 2010; 86:3909.

31. Emanuele C, Salvatore C, Monica C, Nadia F, Daniela C, Salvatore M, et al. Modulation of heat shock protein response in SH-SY5Y by mobile phone microwaves. World J Biol Chem. 2012; 3:34-40.

32. Milosev M, Novakovic M. Mobile phone radiation simulator could be used for testing the effects of microwaves on biological systems. Ser J Exp Clin Res. 2012; 13:31-2. 


\section{Dejstva mikrotalasnog zračenja na kulture mikoorganizama}

Slobodan M. Janković, Milorad Z. Milošev, Milan LJ. Novaković

Fakultet medicinskih nauka, Univerzitet u Kragujevcu, Kragujevac, Srbija

\section{KRATAK SADRŽAJ}

Mikrotalasi su nejonizujući elektromagnetni talasi sa frekvencijama između o, 3 i $300 \mathrm{GHz}$. I ljudi i mikroorganizmi koji žive na organizmu čoveka su izloženi značajnim dozama mikrotalasnog zračenja u svakodnevnom životu. Predmet ovog edukativnog rada je pitanje da li i na koji način mikrotalasno zračenje može da utiče na vitalnost i rast mikroorganizama.

Studije o efektima mikrotalasa na rast kultura mikroorganizama su tražene u biomedicinskim časopisima indeksiranim u bazi podataka MEDLINE od 1966. do 2012. godine. Objavljene studije su pokazale da mikrotalasi deluju na kulture mikroorganizama, bilo da ih ubijaju ili pospešuju njihov rast. Priroda i veličina dejstva zavise od frekvencije mikrotalasa i ukupne energije koju mikroorganizmi apsorbuju. Mikrotalasi male energije i niske frekvencije pospešuju rast mikroorganizama, dok mikrotalasi velike energije i visoke frekvencije uništavaju mikroorganizme. Međutim, dosad nisu ispitivana dejstva mikrotalasa šireg spektra frekvencija i većeg opsega energije.

Uzimajući u obzir moguće štetne efekte mikrotalasa na simbiotičku ravnotežu mikroorganizama i čoveka kao domaćina, neophodno je obaviti dodatna istraživanja delovanja čitavog spektra frekvencija i energija mikrotalasa na rast mikroorganizama.

Ključne reči: mikrotalasi; kulture mikroorganizama; učestalost; apsorbovana energija; rast 